\title{
Citizen science and the right to research: building local knowledge of climate change impacts
}

\author{
Sarita Albagli(i) ${ }^{1 \times} \&$ Allan Yu Iwama (i) ${ }^{2 凶}$
}

The article presents results of a research project aiming to develop theoretical and empirical contributions on participatory approaches and methods of citizen science for risk mapping and adaptation to climate change. In the first part, the paper presents a review of the literature on key concepts and perspectives related to participatory citizen science, introducing the concept of the "right to research". It highlights the mutual fertilization with participatory mapping methods to deal with disaster situations associated to climate change. In the second part, the paper describes and presents the results and conclusions of an actionresearch developed on the coastline between the states of São Paulo and Rio de Janeiro, Brazil in 2017-2018. It involved affected communities as protagonists in mapping and managing risks of natural disasters caused by extreme climate events, by combining citizen science approaches and methods with Participatory Geographic Information Systems (PGIS) and social cartography. The article concludes by pointing out the contributions and limits of the "right to research" as a relevant Social Science approach to reframe citizen science from a democratic view.

\footnotetext{
${ }^{1}$ Brazilian Institute of Information in Science and Technology (IBICT), Brasília, Brazil. ${ }^{2}$ Laboratorio de Ciencia Ciudadana, Universidad de Los Lagos, Los Lagos, Chile. 凶email: sarita.albagli@gmail.com; allan.iwama@gmail.com
} 


\section{Introduction}

he current climate emergency of anthropogenic origin has exerted a broad spectrum of impacts affecting life and the environmental balance of the planet, with the consequent increase in disaster situations at different scales, largely associated with extreme weather events such as droughts and floods (Adger et al. 2018; Anderson et al. 2018; Cinner et al. 2018). The repercussions of current climate change are global and thus require articulated efforts on a planetary scale. But their causes and impacts are different and unequal, and they are especially felt by the most vulnerable regions and social groups (Cutter et al. 2009).

The strategies to face climate change have been based on two main axes: (1) the mitigation of its main causes, and (2) the adaptation and resilience of people as well as socioeconomic and ecological systems to its impacts (IPCC, 2014). Effective responses to the disaster risks related to climate change are still incipient at both government, private sector, and community levels. The current paradigm of disaster risk management focuses on recovery actions (post-disaster actions), and less on prevention and mitigation (Birkmann et al. 2009; Marchezini et al. 2018; Hicks et al. 2019), even though there have been advances in adaptation and preparedness measures to tackle these events (Iwama et al. 2021). Policies and actions at different levels are expected to provide communities with greater capacity and safety to tackle some of the already irremediable effects of climate change. Participation and sensitisation of the most affected and vulnerable social groups, policy makers and private actors in these actions play a decisive role.

Scientific knowledge is crucial for improving decision-making, aimed at supporting mitigation and adaptation agendas as well as at monitoring and providing early warning services and systems. On the other hand, the scope and urgency of these problems pose new issues to the modes of production and circulation of knowledge and information necessary to face them. The complexity and difficulty of accessing relevant data to address the causes and impacts of climate change have hampered their use and social appropriation, as well as cooperation in this area. Participatory and community-based approaches and methodologies have shown promising results for disaster risk management, as they encompass multiple dimensions and factors influencing the resilience of communities (Ensor et al. 2016; Kondo et al. 2019). In this context, citizen science is increasingly perceived as playing a role, promoting science dissemination and social participation.

This article presents results of a research project aiming to develop theoretical and empirical contributions on participatory citizen science for mapping disaster risks of climate change. It argues that the urgency and complexity of responding to disaster risk situations associated to or amplified by climate changes place new demands and highlight the need for new approaches to citizen science, where Social Sciences have a role to play. In this sense, it mobilises the concept of the "right to research", coined by the Indian anthropologist Arjun Appadurai (2006), proposing a broader definition of research that stresses the relevance of fostering the production and documentation of knowledge by common people as a way of enabling them to make their voice heard, particularly in situations of social and environmental vulnerability.

In the first part, the paper presents a review of the literature on the key concepts and perspectives related to participatory citizen science, introducing the concept of the right to research. This section ends by pointing out the mutual fertilization with participatory mapping methods to deal with disaster situations associated to climate change. In the second part, the paper presents the context, methods, and results of the action research component of the project, developed along the Southern coast of Brazil. This research component mobilised local affected communities as protagonists in mapping and managing the risks of floods and landslides resulting from the impacts of climate change, by combining citizen science approaches and methods with social cartography and Participatory Geographic Information Systems (PGIS). The article concludes by highlighting the contributions and limits of the "right to research" as a relevant Social Science approach to reframe citizen science from a democratic view.

\section{Citizen science from a democratic perspective and the right to research}

Climate change addresses new issues and poses new questions to the information regime on science, technology, and innovation. It is argued that "the climate regime has become substantively more complex over time and because there is now a wider set of actors cities, states, business, civil society [...]" (Morgan et al. 2014, p. 8). In this context, the debate on open science has gained prominence, mainly in two of its axes: open research data and citizen science (Albagli et al. 2015).

The opening of research data--to make it freely accessible, shareable and (re)usable - has been pointed out as a crucial element for increasing the speed, quantity, and quality of scientific research results. But it does not guarantee the necessary capacities for the social production, appropriation and use of data, nor does it question the kind of knowledge that is made visible and recognised as relevant. It is also crucial to provide means and conditions of valuing and considering the experiential knowledge of different social and cognitive actors (Collins and Evans, 2002), and to make room for citizen innovation (Sauermann et al. 2020; Albagli et al. 2019).

Citizen science has attracted increasing attention as a tool to cope with social, environmental, and territorial issues. It has consisted mainly of voluntary non-scientist collaboration in collecting and interpreting data useful for research, such as images, sounds and other types of records, improving research results, and lowering costs (Irwin, 1995; Bonney et al. 2009; Haklay, 2013).

Citizen Science initiatives have been facilitated by new computational resources--graphical user interfaces, photo upload and validation, web applications based on geographic information systems, Volunteered Geographic Information (VGI), simple online data feed systems--which can be used in smartphone applications and other mobile devices that make it possible to connect directly to the Internet. These digital platforms and tools facilitate the connection and contribution of volunteers. Supported by digital tools and platforms, citizen science associates indepth data obtained from the proximity and situated experience of local observers with large amounts of data from the contribution of many individuals territorially dispersed (crowdsourcing), thus linking big and small data. When combined with sophisticated technological devices such as satellite images and other remote sensing technologies, it opens new possibilities of spatial and temporal approaches for socio-ecological research (Dickinson et al. 2012; Bonney et al. 2014).

On the other hand, criticism has been expressed of the fact that citizen science initiatives "have normally taken place in affluent locations, excluding illiterate or literate populations living in remote areas" (Comandulli et al. 2016, p. 36). By contrast, the concept of "extreme" citizen science is advocated (Stevens et al. 2014), claiming "to allow any community, anywhere in the world--from marginalized groups living on the peripheries of urban areas to groups of hunters and gatherers in the Amazon 
rainforest--start a Citizen Science project to deal with their own issues." (Comandulli et al. 2016, p. 36). Therefore, it is argued that a quantitative and pragmatic perspective on citizen science--to increase the speed, reach and volume of research results--should be combined with a qualitative and democratic perspective: to promote greater porosity and dialogue between science and the broad spectrum of spaces and actors of knowledge production (Albagli et al. 2015; McCall et al. 2015).

This view fits with Arjun Appadurai's claim that the entitlement to perform research should be considered as a right. The author argues that, in a world of rapid change, informed citizenship is a demand of full and democratic citizenship--as opposed to marginal citizenship--and should be seen "as belonging to the family of rights". This makes research a crucial capacity that should be "part of the lives of ordinary people" (Appadurai, 2006, p. 173), as "a genuinely inclusive and universally available capacity" (Appadurai, 2006, p. 169).

From this perspective, Appadurai proposes the concept of the "right to research", that is "the right to the tools through which any citizen can systematically increase that stock of knowledge which they consider most vital to their survival as human beings and to their claims as citizens." (Appadurai, 2006, p. 168). By research Appadurai designates "a specialised name for a generalized capacity, the capacity to make disciplined inquiries into those things we need to know", as a means of supporting decision making that requires information "beyond their current knowledge horizons" (Appadurai, 2006, p. 167). In this respect, the author stresses "the value of documentation as intervention", as a tool which brings "the capacity to research within the reach of ordinary citizens" (Appadurai, 2006, p. 175). Documentation--meaning here the ability of people to register their observations and to share them as data and information--is at the core of citizen science, increasingly making use of digital platforms and tools.

Appadurai connects the right to research to "the capacity to aspire", understood as "the social and cultural capacity to plan, hope, desire, and achieve socially valuable goals" (Appadurai, 2006 , p. 176). However, he points out that this capacity is unevenly distributed in society. This link is at the core of social change: "Without aspiration, there is no pressure to know more. And without systematic tools for gaining relevant new knowledge, aspiration degenerates." (Appadurai, 2006, p. 176).

When mobilised as a means of empowering non-scientists in formulating questions, hypotheses and analyses, citizen science is in line with Appadurai's proposal. From this perspective, the engagement of non-scientists as volunteers or protagonists in research activities is not only motivated by pleasure, leisure, or even altruistic reasons. It is also driven by the citizens desire to intervene more actively in issues that directly interfere in their lives, and whose decisions are often based and restricted to expert opinion.

The connection between the right to research and the right to the city--a notion developed by Henri Lefebvre in the 1960s that can be extended to the right to the territory in a broader sense--is in turn proposed by Udvarhelyi (2011). She argues that engaging in research is not only "a means to political participation", but also a way to develop "counterhegemonic action and practice" (Udvarhelyi, 2011, p. 391). This requires a "critical look at how, where, why, by and for whom knowledge [about the territory] is produced" (Udvarhelyi, 2011, p. 388-390). She adds: "This is why the production and possession of knowledge, access to information and the power of interpretation all become central to the struggles that take place on the social and spatial battlefield of the city." (Udvarhelyi, 2011, p. 388).

Recognition of the right to research of individuals, communities, and social groups as coproducers of knowledge, from the beginning and at various stages of research, can contribute to new approaches and cultures in ways of doing science and make the resulting social learning processes more robust. In this sense, citizen science may challenge the traditional bases of knowledge production (David-Chavez and Gavin 2018; Lam et al. 2020) and may also bring about greater social impact (Shirk et al. 2012; Haklay, 2013; Kondo et al. 2019). The relevance of combining multiple knowledge systems beyond scientific knowledge, as an extended peer community--or post-normal science (Funtowicz and Ravetz, 1997; Tengö et al. 2017)--has also been acknowledged. In particular, research on collective intelligence indicates that diversity matters, and that new leaps of logic, innovation, and invention are more likely to arise when people of different backgrounds and abilities work together toward a common goal (Dickinson et al. 2012).

The next section focuses on the possible applications of citizen science combined with participatory mapping to cope with disaster situations associated to climate change.

\section{Citizen science, participatory mapping and research in climate change and disaster situations}

The relevance of citizen science in disaster risk reduction (DRR), particularly regarding environmental, social, and sanitary hazards, has been demonstrated (Hicks et al. 2019; Marchezini et al. 2018). Citizen science can promote community-based data collection and record local observations on the effects of climate change. It may be instrumental for improving research on climate change patterns, as well as for innovating in statistical analysis of heterogeneous data, thus contributing to the advancement of scientific knowledge. It can assist in the understanding of local and global patterns of climate change, give substantive indications of its effects, as well as in the calibration and refinement of services and instruments related to weather forecast, flood alert, among others, contributing to the early warning of hazards that help assess and manage impacts (Reyes-García et al. 2019; Chari et al. 2019; Savo et al. 2016; Hicks et al. 2019; Marchezini et al. 2018; Mosites et al. 2018).

However, initiatives for participatory risk mapping are still peripheral and not yet systematically incorporated into disaster risk management (Keefer et al. 2011; Di Giulio et al. 2014; Iwama et al. 2016; Hicks et al. 2019; Serrao-Neumann et al. 2020). The "triple disaster" - earthquake, tsunami, nuclear meltdown--in Japan, in 2011, put in evidence the role of citizen monitoring and bottom-up decision-making processes to tackle these situations, making room for participatory mappings and participatory science to be considered in public policies in a more systematic way (Kenens et al. 2020). Citizen science has been recognized as a way of promoting public engagement, especially of affected communities, in adaptation, mitigation and resilience actions (Hicks et al. 2019; Paul et al. 2020). Studies conducted in different contexts (Mercer et al. 2012; Cadag et al. 2018; Marchezini et al. 2018; Kondo et al. 2019; Kenens et al. 2020; Iwama et al. 2021) have shown that citizen engagement empower people to better understand and act in response to disaster and impacts from extreme or slow-onset climate events.

Participatory action research (PAR) methodologies have been tested to engage local affected communities as protagonists in risk mapping of natural disasters associated to extreme climate events, and in designing adaptation strategies to these occurrences (McCall and Peters-Guarin 2012; Iwama et al. 2021; Trajber et al. 2019). It is expected that they can increase the effectiveness of actions to mitigate and adapt to climate change. "By involving those most affected by climate change in environmental science and advocacy, not only are they better positioned to understand and respond to change but to participate in governance around 


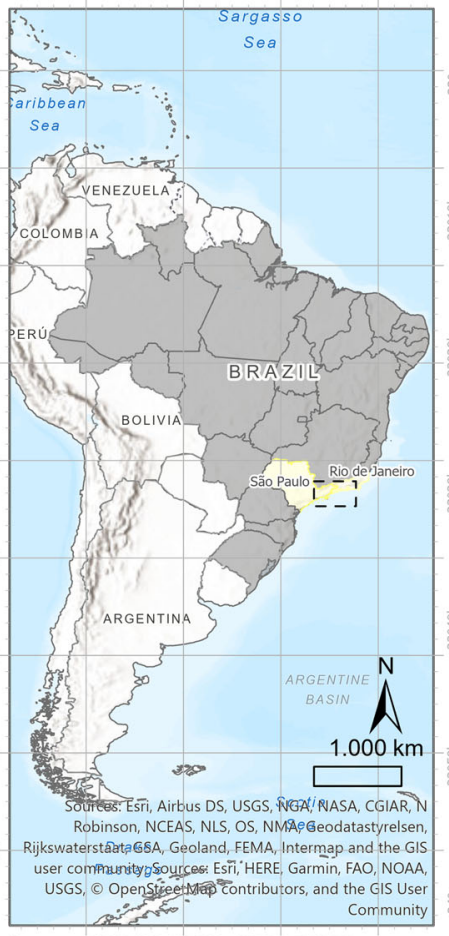

Source: CBH-LN; IBGE; OTSS; ESRI Base map Elaborated by Allan Yu Iwama (2020)
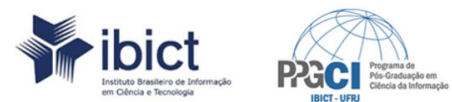

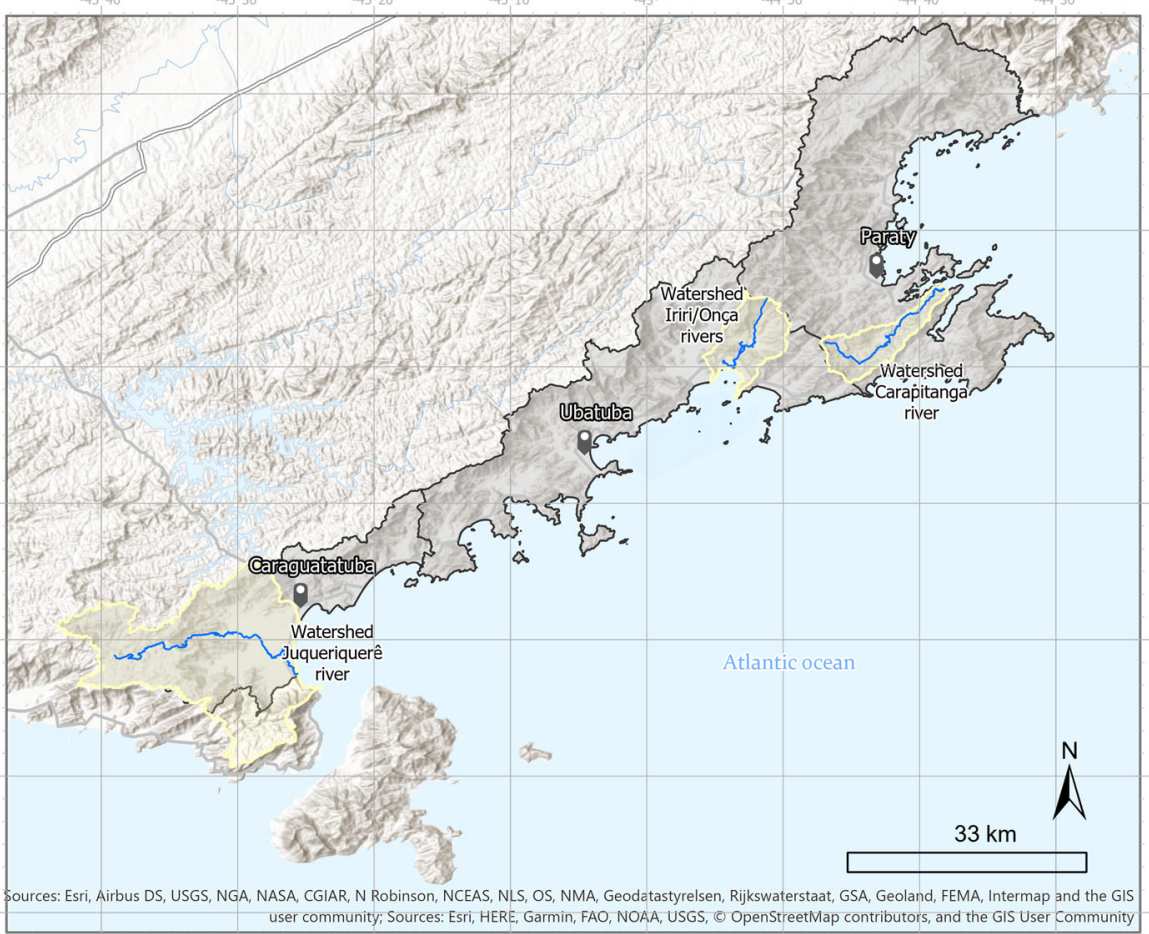

user community; Sources: Esri, HERE, Garmin, FAO, NOAA, USGS, 0 OpenStreetMap contributors, and the GIS User Community

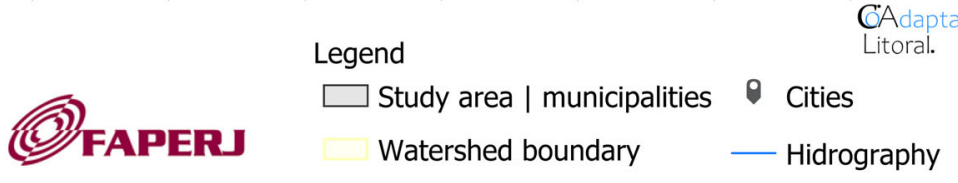

Fig. 1 Study area: Caraguatatuba and Ubatuba, in the state of Sao Paulo (the Juqueriquere river basin and Iriri/Onça river basin, respectively). Paraty, in the state of Rio de Janeiro (the river basin Carapitanga). Source: Digital maps from CBH-LN; IBGE; OTSS; ESRI base map.

climate issues." (Baumgartner and Zarestky, 2017). In the same direction, in the Paris Agreement on Climate Change, there is an explicit recognition that the axis of adaptation must also be based "as appropriate, on traditional knowledge, on the knowledge of indigenous peoples and on local knowledge systems" (UN, 2016).

The action research reported in the next section highlights the potentials and difficulties of mobilizing citizen science from a more participatory and democratic perspective, in line with the concept of the right to research.

\section{Experimenting on the ground}

The action research component of the project was carried out from 2017 to 2018 in the region that lies between the Northern coast of the state of São Paulo State (SP) (from the cities of Caraguatatuba and Ubatuba) and the Southern coast of Rio de Janeiro State (RJ) (up to the city of Paraty) (Fig. 1). That region was selected because it encompasses critical areas of landslide and flood risks (Iwama et al. 2014), as well as local communities with potential for involvement in participatory experiments (Albagli et al. 2019). It is made up of a mosaic of protected areas, including indigenous lands and quilombos (areas occupied by slave descendants), playing an important role in the preservation of natural resources.

It should be noted that recurring problems affecting urbanization processes in Brazil - such as land concentration and the absence of consistent housing policies; irregular occupation of hillsides and riverbanks; inadequate provision of infrastructure and utilities, especially precarious supply of drinking water and basic sanitation - make risk and vulnerability situations even worse as the intensity and frequency of extreme weather events increase, particularly in coastal areas (Merkens et al. 2016). The action research component of the project was developed following three steps (Fig. 2).

Using social cartography, this work engaged three local community groups in the collective production of their own maps of social risk and of evacuation routes as well as in the adaptation of strategies at a local level--maps of flooding, landslides, and sea level rise threats. These participatory maps were vectorized using the QGIS software--Participatory Geographic Information Systems (PGIS) - and compared to data produced by scientific and technical institutions. In addition, interviews were conducted with long-time residents. These steps are detailed below.

Phase I - GIS and SDI. The first step involved preparing a geodatabase with QGIS, a free/open-source Geographic Information System, using data from the Geological Survey of Brazil (CPRM) at a scale of 1:25.000. The purpose was to indicate areas of low, medium, and high susceptibility to flooding or landslides, defined according to the occurrence of these risky events (Fell et al. 2008). See Table SM1 in Supplementary material section. The data produced by scientific institutions are often historically dated, while locally collected data facilitates its agile updating and the covering knowledge gaps.

For the analysis of flooding susceptibility, three steps were adopted: 1 - morphometric analysis: quantitative analysis of the interactions between physiography and its hydrological dynamics that provides knowledge of river dynamics; 2 - HAND (Height Above Nearest Drainage) (Rennó et al. 2008) algorithm which 

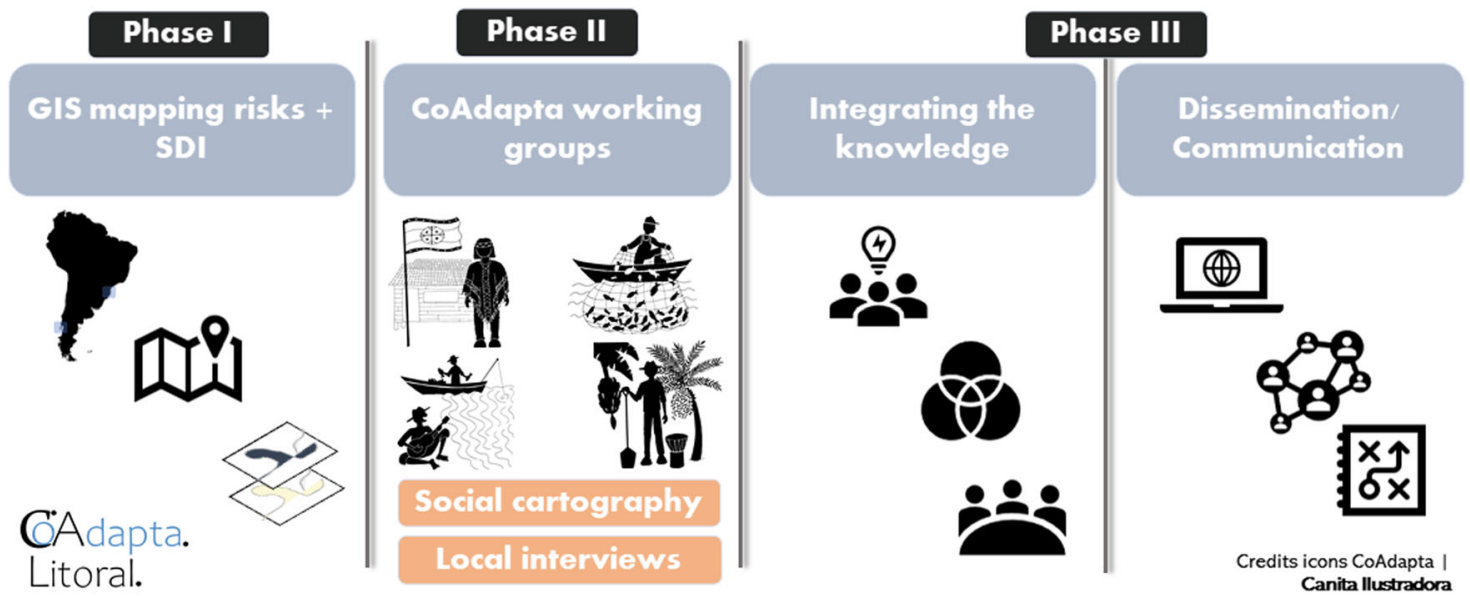

Fig. 2 Methodological approach. Phase I - GIS mapping and SDI, Phase II - CoAdapta working groups (WGs) and Phase III - integrating the knowledge and communication results.
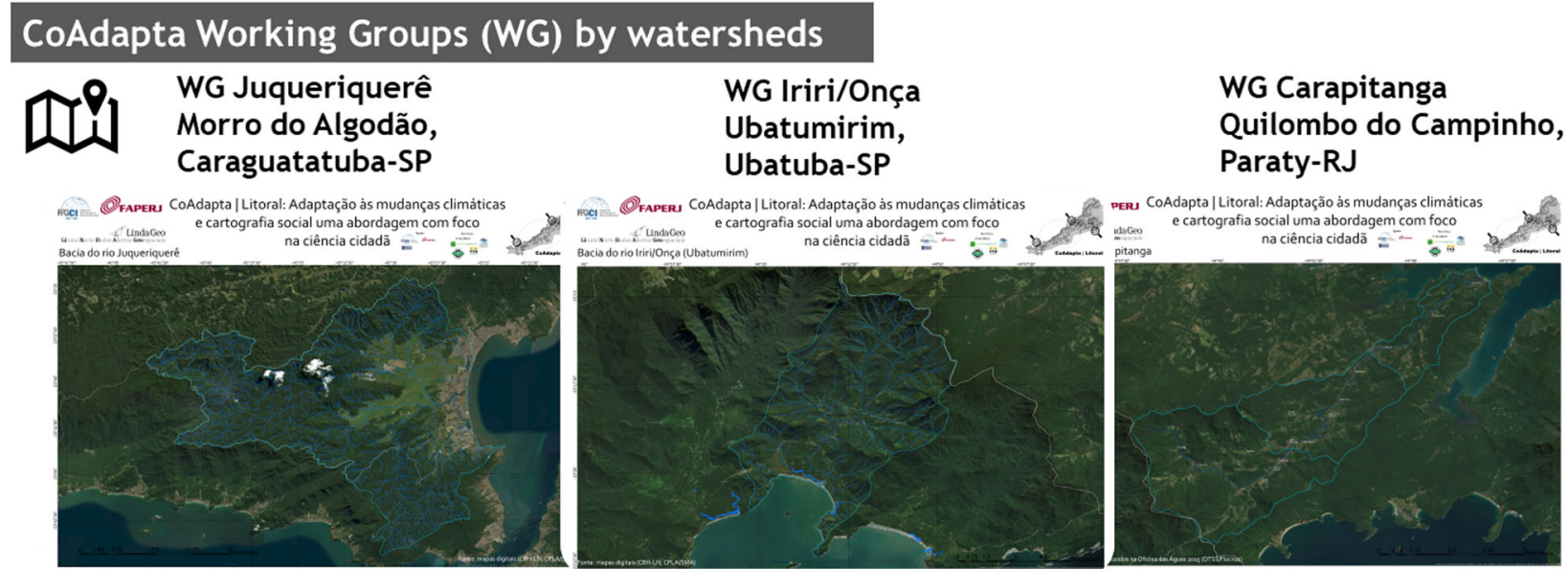

CoAdapta | community researchers
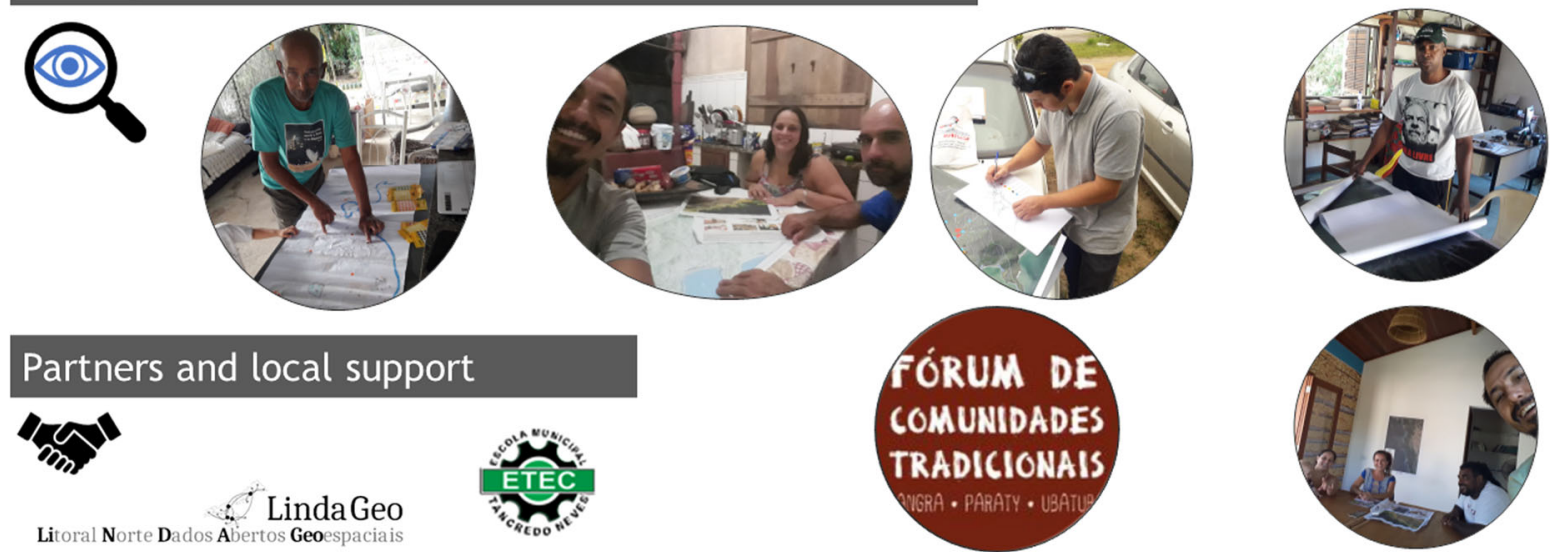

Fig. 3 CoAdapta working groups (WG): WG Juqueriquerê (Caraguatatuba-SP), WG Iriri/Onça (Ubatuba-SP) and WG Carapitanga (Paraty-RJ).

measures the altitude difference of the Digital Elevation Model (DEM) and the respective flow into the nearest drain, considering the superficial flow path that topologically links the points of surface with the drainage network, with applications using highresolution spatial data to urban areas (Nobre et al. 2016); 3 - the morphometric analysis overlapping with the HAND model results was carried out by means of Boolean logic, classifying it at high, medium and low susceptibility to flood (Table SM2).
Phase II - CoAdapta working groups Local meetings. A total of 15 meetings was organized with local groups selected for their activism on issues of local community interest. The identification and selection of participants for these meetings were based on previous research involving local communities in the region (Iwama et al. 2016; 2014; Di Giulio et al. 2014; Albagli et al. 2019), as well as consultations with the Forum of Traditional Communities of Angra dos Reis, Paraty and Ubatuba. These meetings 
Table 1 CoAdapta working groups (WGs) to participatory action research.

\begin{tabular}{llll}
$\begin{array}{l}\text { CoAdapta Working group | Watershed/ } \\
\text { municipality }\end{array}$ & Community & Traditional/Local leadership & $\begin{array}{l}\text { Community members } \\
\text { engaged (n) }\end{array}$ \\
\hline Juqueriquerê River Basin - Caraguatatuba (SP) & $\begin{array}{l}\text { Morro do Algodão } \\
\text { Community } \\
\text { Ubatumirim Community }\end{array}$ & $\begin{array}{l}\text { 1 Local leadership } \\
\text { Iriri/Onça River Basin - Ubatuba (SP) }\end{array}$ & $\begin{array}{l}\text { artisanal fishers } \\
\text { 2 Traditional leadership - quilombolas }\end{array}$ \\
Carapitanga River Basin - Paraty (RJ) & $\begin{array}{l}\text { Quilombo Campinho } \\
\text { Community }\end{array}$ & 17
\end{tabular}

aimed at: (1) presenting the joint work proposal of social cartography as a strategy for work focused on citizen science; (2) working collaboratively on questions for the interviews of local residents, in order to capture their perceptions about risks and climate change adaptation in their territories to face these events; (3) presenting and delivering field activity material (questionnaires, audio recorders, support maps for social cartography); (4) setting goals and deadlines for activities, including the production and dissemination of work.

Community groups. From these meetings, three working groups (WGs), called CoAdapta local teams, were formed, each one corresponding to a river basin ${ }^{1}$ and counting on the participation of community leaderships. They were: (WG1) the Morro do Algodão Community in the Juqueriquerê River Basin, in Caraguatatuba, SP. This region has been undergoing significant changes in its landscape and occupation due to the installation of a gas treatment unit in the municipality and the expansion of access roads (Teixeira and Iwama, 2017); (WG2) the UbatumirimCommunity in the Iriri/Onça River Basin, in Ubatuba, SP. The caiçara community has been fighting for their territory for years due to the conflict over the use of natural resources caused by the overlapping of protected areas (Simões et al. 2016); (WG3) the Quilombo Campinho Community in the Carapitanga River Basin, in Paraty, RJ. Quilombola communities have been fighting for their rights for land for decades (Fig. 3).

After the capacity building of these working groups, the snowball sampling (Goodman, 1961) was adopted to select participants for a social cartography activity and for interviews, based on the network of contacts of the identified leaders. Each local leader was asked to indicate individuals in their communities (respectively the working groups WG1, WG2 and WG3), considering the following criteria: (i) people aged over 60; (ii) period living in the territory; (iii) experience with a disaster event (e.g., landslides and floods after intense rainfall experienced by residents of Morro do Algodao in 1967). Interviews were carried out by local research teams for two months. The results of the interviews were then analysed, taking into account the literature on perceptions of climate change risks (Leiserowitz, 2006; Slovic et al. 2010; Di Giulio et al. 2014; Iwama et al. 2016: Bradley et al. 2020).

Social cartography. The CoAdapta WGs carried out the training of community researchers in the use of social cartography for disaster risk mapping. Social cartography activities were developed with CoAdapta WGs to map and record flood and landslide risk areas, vulnerability situations and the strategies used in those situations, employing QGIS open-source software and semistructured interviews. In these activities, both supporting maps with satellite background images and paper panels were used. Satellite maps supported the identification of landmarks - such as health centers, schools, bridges--while mental maps revealed their memories and told stories about territorial dynamics.
Social cartography consists of carrying out mapping according to a community's own vision vis a vis maps produced by experts, incorporating some concepts and techniques of cartography and geoprocessing (e.g., scale, symbology, representation, metadata). Social cartography methods are widely used in natural resource identification and management, in socio-environmental hazard mapping as well as in legitimising customary land and resource claims (McCall, 2014). Participatory mapping has been adopted as a way of supporting local communities and traditional communities to produce knowledge about their territory and, in this way, empower them to claim their rights more efficiently and to engage in participatory spatial planning (Crampton, 2001; Acselrad H org. 2013; Marchezini et al. 2017). Social cartography has also been combined with geotechnologies such as GPS (Global Positioning Systems) or GIS (Geographic Information Systems), which have become increasingly accessible to nonspecialists (McCall, 2014; Haklay, 2013; Marchezini et al. 2017; Albagli et al. 2020), culminating in a Participatory Geographic Information System (PGIS).

Interviews. Interviews were conducted by community researchers in their own communities. The target audience consisted of people living longer in the territory (people sixty years old or above) and younger generations socially and politically active in the territory. A semi-structured questionnaire was constructed in conjunction with these groups to identify changes in the landscape, risk areas, extreme rain or extreme drought events and implications for land use and disaster events. The questions were organized into five themes: (i) interviewee profile, (ii) residence time, (iii) disaster risks, (iv) prevention and adaptation, and (v) forms of communication and visualization of knowledge and information ${ }^{2}$.

The interviews were also intended to support the mobilisation of the local community in participatory activities for the identification of geodynamic risk areas (flood, landslides, erosions, coastal erosions, among others) and situations of exposure and social vulnerability (constructions near riverbanks, risk situations for housing, number of teenage or elderly women, people with physical or mental difficulty). Each questionnaire was accompanied by a consent form to participate in the research, with a total of 46 people $(n=46)$ interviewed by community researchers. The Juqueriquerê community group had $n=12$ respondents; the Iriri/Onça community group had $n=17$ respondents; the Carapitanga community group had $n=17$ respondents (Table 1 ).

Phase III - Integrating knowledge and dissemination/communication. The mappings resulting from social cartography were inserted into the geographic database structured using the free software QGIS (Phase I), to make it available to local groups. To this end, workshops on Geographic Information Systems (GIS) using QGIS were organized to present the tool and enable these groups to build their own databases, as well as to access 
Table 2 Study steps by each CoAdapta WGs.

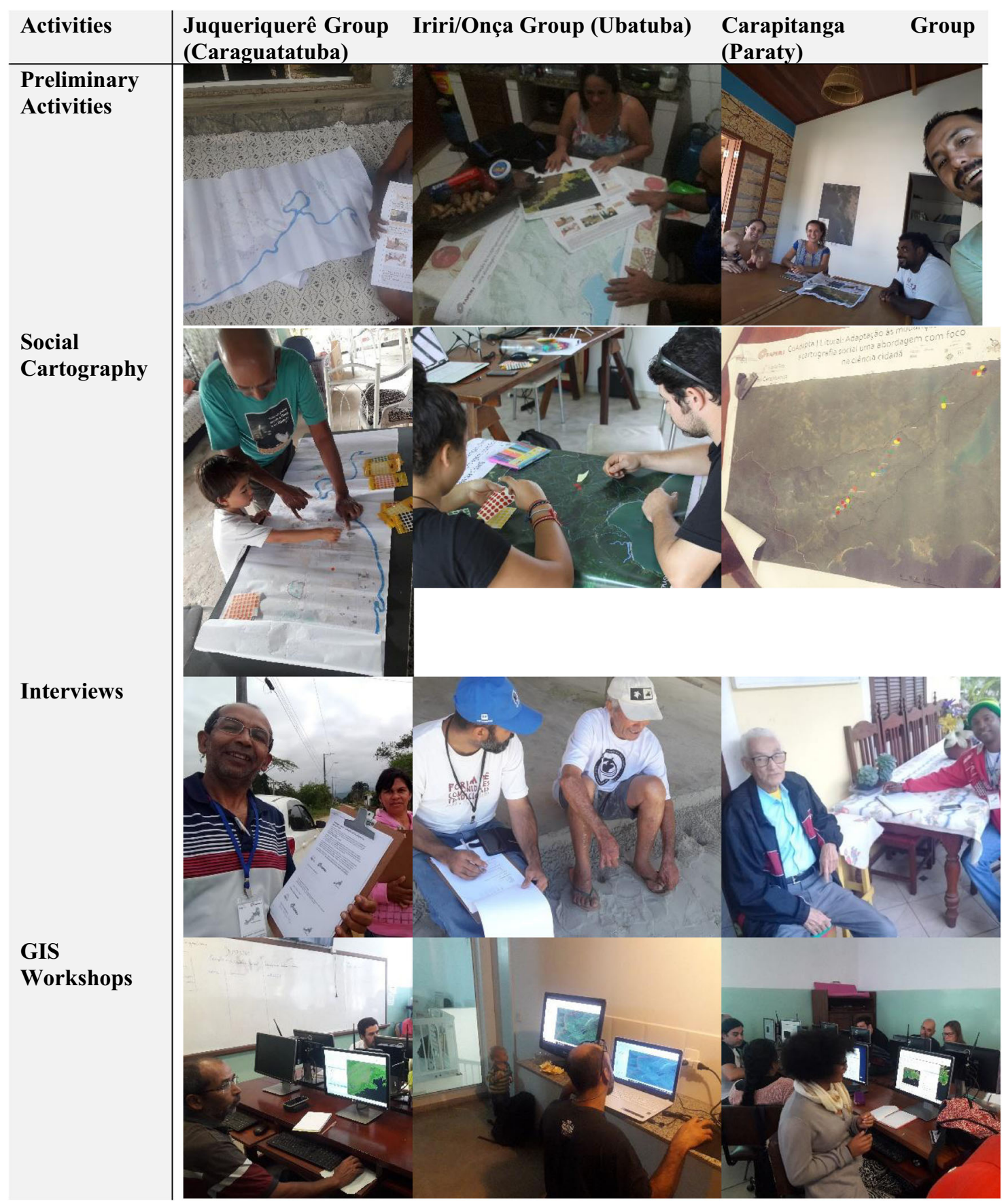

Source: Photo records (Allan Iwama and community researchers 2018).

available information produced by research and governmental institutions about their territories. In these QGIS workshops, preliminary results of social cartography were crossed and compared with the official mapping of risk areas produced by the Geological Service of Brazil (CPRM) and the Institute of Technological Research (IPT).

These different stages of the empirical study are shown in Table 2.

\section{Results}

Participatory citizen science associated with the use of community-based data feeding tools. The action research helped to demonstrate how the different types of maps produced in the study could be integrated, combining scientific knowledge with local knowledge and enhancing the identification of risks and adaptation strategies. Figure 4 show the 3D maps of susceptibility of flood and landslides overlapping with hazards from social cartography. 


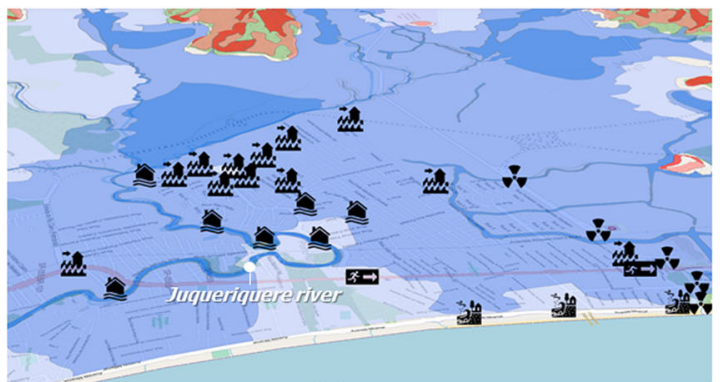

(a)

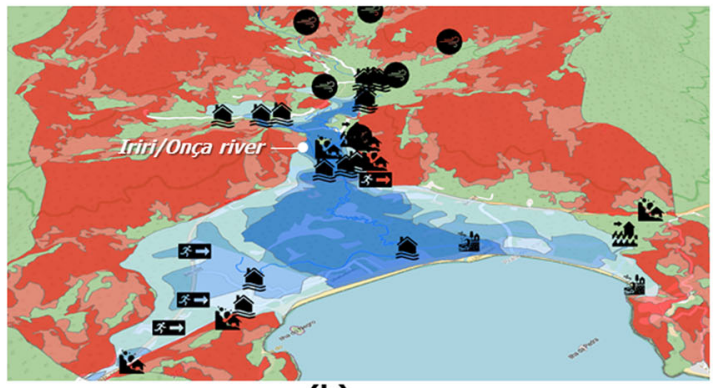

LEGEND

Flood

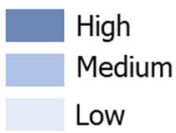

(b)

Landslide

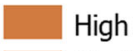

Medium

Low

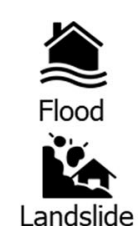

Landslide

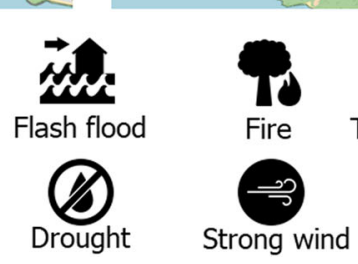

Fig. 4 The representation of 3D maps with social cartography maps overlapped on digital maps of susceptibility areas (CPRM 2016) using QGIS software. a Juqueriquere River Basin (Caraguatatuba); (b) Iriri/Onça River Basin (Ubatuba); (c) Higher and (d) Lower Carapitanga River Basin (Paraty). Source: digital maps from CPRM (2016); MMA (2018). Icons from Noun project.

Maps and scales overlapping. The overlap of maps (social cartography and technical scientific cartography) provided an opportunity for joint reflection by the community researchers and their neighbours on the scope of the areas at risk in the selected territories, broadening their view as to the boundaries of the watersheds. For example, flood and landslide susceptibility maps originally used by the Geological Survey of Brazil (CPRM) and Technological Research Institute (IPT), on the 1:25,000 mapping scale, indicate areas on a smaller scale when compared to those produced through social cartography by local communities--usually at scales more detailed such as 1:1,000 to 1:10,000. This reflection allowed local communities to have a broader view of their watershed, expanding their perception of the specific risks occurring where they live. It was from this experience that they were also able to visualize strategies to design exit points (evacuation routes) in events of flash flood or floods.

In the Juqueriquere river basin (Fig. 4a), local communities have indicated the existence of events of flash floodS in areas of medium flood susceptibility--specifically in the Morro do Algodao district. The risks associated with gas leaks pose an additional danger besides floods in these areas (Iwama et al. 2013; Teixeira and Iwama, 2017). According to a local community member:

"...since the installation of the Gas Treatment Plant (the UTGCA - Usina de Tratamento de Gás de Caraguatatuba) in 2006, the gas pipelines have been built underground. From time to time, there is a gas leak in the pipe valves, and these gas leaks are not always resolved in time. Sometimes people had to evacuate the area to protect themselves. Furthermore, we know that there are floods here, and when there is a lot of rain combined with the effects of high tide, it is a catastrophe" [Local community, in 2017]
Temporality of risks. Based on the interviews, it was possible to observe the period, seasonality, frequency, and duration of risks. In addition, there are points indicated on the maps of social cartography where coastal erosion frequently occurs in the three watersheds. The most affected areas were beach infrastructure (kiosks at Praia das Palmeiras) in the Juqueriquere river basin; and fluvial and coastal dynamics in the Iriri/Onça and Carapitanga river basins, with direct effects on fishing for Caiçaras, Quilombolas and indigenous communities (Figs. 4a-d). Also, in both the Iriri/Onça and Carapitanga river basins, strong winds have been reported that affect the banana plantations (mainly in the Ubatumirim district) and house roofs. The local community said:

"...strong winds occur mainly in the months of July and August when they end up damaging the banana plantation or untangling the houses. [...] often the local people call it "northwest wind („vento noroeste"), but it seems that now it has become more and more frequent..." [caiçara de Ubatumirim, 2017]

In the Carapitanga river basin, the occurrence of high intensity drought in 2015 was reported. It was a large-scale event, which occurred throughout the state of Sao Paulo and reached the south of the state of Rio de Janeiro, affecting the water supply and causing a reduction of water in springs and water courses (Pacheco et al. 2017; Anazawa, 2018). As a positive side effect, a Water Workshop for the Carapitanga river--"Oficinas das Águas"--was created, a joint initiative of the Observatory of Sustainable and Healthy Territories (OTSS in Portuguese) and the Traditional Communities Forum of Angra dos Reis, Paraty and Ubatuba. As a result of this workshop a collaborative map of 


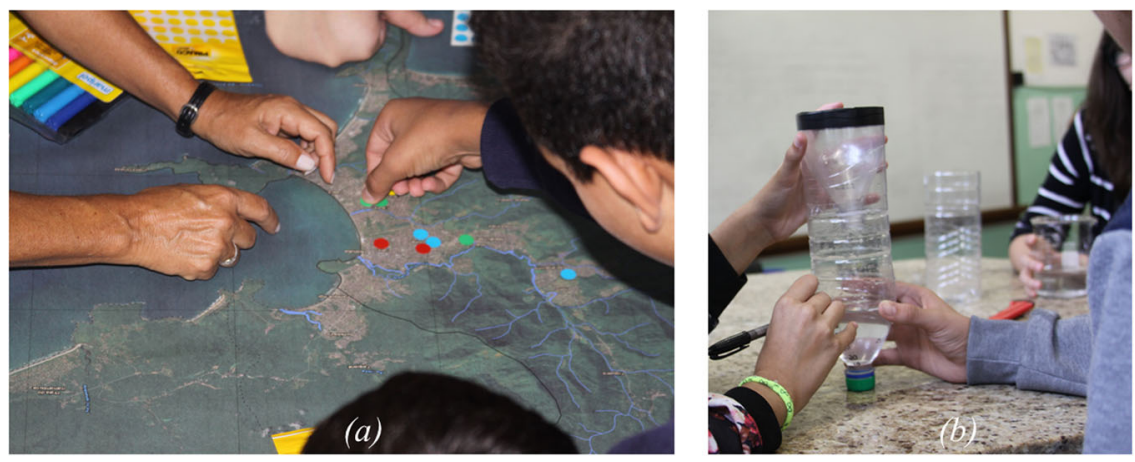

Fig. 5 Activities in Presidente Tancredo de Almeida Neves Municipal School, in Ubatuba - Southeast of Brazil. a Social cartography to identify risks around the school in Ubatuba downtown; (b) Artisanal pluviometer to build a network of rain monitoring. Source: Iwama (2018).

water scarcity and other elements in the Carapitanga river basin was produced ${ }^{3}$. An oral testimonial about this event was:

“...Between 2014 and 2015, there was a major drought here and the river waters decreased a lot, which provoked a certain level of conflict in the area... And it was good that it brought us together around a basin which sometimes is very dry, sometimes overflows..." [Leadership of the Traditional Community Forum of Angra, Paraty and Ubatuba, 2018]

In the Iriri/Onça river basin, agroforestry systems have been increasingly used as a key strategy for food security and local production of organic food, and they have also been important towards reducing risks of landslide disasters:

"I noticed the importance of the way of planting, using agroforestry, to prevent soil erosion and flood, and people reacted positively to this approach, [...] the land is better looked after" [Caiçara community in the Iriri/Onça watershed, 2018]

The project also included activities of social cartography, storytelling and spatial databases built by the communities to feed the Cemaden-Educacao platform ${ }^{4}$, an interactive national citizen science platform to collect, organize, share, and exchange experiences for education and disaster risk reduction. This platform includes a social cartography approach, oral histories, crowdsourcing and other participatory methods.

Legend. The legends of the risk maps and indications about the degree or level of risk (expressed in colours) were made according to the perception and experience of the communities in risk areas. To this end, the following questions were submitted to the participants: "How would you represent this risk area?"/ "What degree of risk did you attribute to this danger?"/ "What colour would you use to indicate this type of danger or degree of risk?". After that, participants were encouraged to make comparative reflections between the results of the maps, the legends they produced through social cartography, and the risk mappings made by government institutions.

Capacity building through "learning by doing". Action research resulted in several types of learning: (i) the training of community researchers in the production of maps via social cartography, in the use of GIS for data geovisualization, and in conducting interviews; (ii) expanding the practical learning of the project's scientific team in the use of action research methodologies, social cartography, and storytelling for the purposes of citizen science; (iii) two-way learning between interviewers and interviewees from the respective communities on the effects of extreme weather events in their territories and possible adaptation strategies.

Community strategies. This process provided an opportunity for local communities to design their own strategies for identifying risks associated with floods, flash floods, landslides, strong winds, and gas leak hazards, and for identifying evacuation routes to safer locations. The exercise demonstrated that participatory experiments in co-producing knowledge and information about the territory not only contribute to reflections on their actions or non-actions in the face of risk, but also produce practical results on what to do and where to go, when they are in situations of imminent danger.

Partnerships with local schools. In addition to community groups, a partnership was also established with the municipal school Presidente Tancredo de Almeida Neves in Ubatuba, with the participation of the pedagogical coordinator, the geography teacher and 40 high school students. The following activities were carried out: the construction of handmade rain gauges; social cartography workshops; and training in the use of Geographic Information Systems using the free software Quantum GIS (Fig. 5).

\section{Discussion}

The points for discussion raised by the results obtained in the study are presented below. They also demonstrate the challenges and barriers to obtaining the expected outcomes.

Integrating knowledge from different systems. The mapping of risks through social cartography, together with the mapping of risks produced by official institutions, illustrate the possibilities of integrating results between the accumulated local knowledge and the scientific knowledge produced about the regions ${ }^{5}$. With these results, the possibilities for mapping risk areas and strategies for adapting to the risks of disasters associated with climate issues are expanded, connecting different types of knowledge, and promoting greater engagement of communities living in these areas. Our results showed the possibilities and potential of ways to work with data produced from local knowledge, such as newsletters and spatial databases using digital maps through the CemadenEducacao platform ${ }^{6}$ (Trajber et al. 2019). However, there are still no applications of this material integrated with the official risk and vulnerability maps in the region. In Brazil, there are few studies that have integrated different knowledge systems--the scientific, traditional, and local knowledge--into disaster risk maps. Some studies have sought this integration (Marchezini et al. 2019; 2017; Iwama et al. 2014), but more systematic studies are still needed showing the methodological challenges for 
supporting a community-based disaster risk management and for the construction of a public policy agenda to climate change.

Social technologies and the right to research. The experiment promoted the building of the communities' capacities in the use of community-based data-feeding tools and systems. It was noted that community researchers had difficulty handling the geovisualization tool and visualizing it through graphics, even with the training they received. In addition, intermittent access to the internet does not allow them to properly access the platform and use the interactive map. Where the lack of a digital platform still creates access problems in communities farther from urban centers, it is appropriate to use satellite printed maps in social cartography activities to signal critical locations and to identify escape routes. Despite the increased use of digital platforms and social technologies, the citizen science initiatives committed to community participation need to contribute to building local working groups that can support each other in data collection and local knowledge production.

On the one hand, digital platforms can support large-scale citizen science initiatives. Those initiatives based on social technology--such as social cartography--focused on collaborative knowledge production, can go beyond crowdsourcing methods for data collection. They should promote a closer involvement of the community in co-creation processes, where the non-scientist participants are actively involved in the research stages or even conduct research independently (Shirk et al. 2012; Haklay, 2013; Paul et al. 2018; Hicks et al. 2019; Marchezini et al. 2018).

Our study indicates that participatory citizen science, when codesigned with traditional and local communities from the right to research perspective, strengthens bonds and trust between the community and scientific researchers. The participation of community members not only as data collectors, but as active participants in the development of the research, is increasingly adopted, especially in interdisciplinary and transdisciplinary research, leading to a more dialogic form of communication. This can increase the inclusion of social technologies for citizen monitoring that meets local demands and favours community development, providing autonomy, resilience, and the capacity to adapt to the effects of climate change in their daily lives.

Building a common agenda. Efforts were needed to build a common agenda for the three community groups to make the execution of the three proposed stages in the project compatible and coordinated, whilst still preserving the specificities and contexts of each territory. Based on community participation in the CoAdapta project activities, each working group took advantage of their experiences to establish their own agenda for strengthening their community, using the lessons learned in the project (interview methods, data collection using mobile and GPS applications, and territory mapping programs). A Whatsapp group was created to facilitate the updating of information among study participants and to motivate the joint progress of the work. From these meetings, the participants of the three groups installed the software on their personal computers or those of the Community Association of Residents, starting their own surveys. Furthermore, in addition to the CoAdapta wiki ${ }^{7}$ and website ${ }^{8}$, the records of activities in a field diary of community researchers were shared online, creating a channel to develop common protocols and share concepts/points of view as transparently as possible.

Development of bonds of trust. The action research component of the project lasted one year. The feasibility of executing its objectives in this short time frame was only possible due to previous experiences in projects involving these communities (Iwama et al. 2016). This facilitated the building of bonds of trust and the establishment of the communication channels necessary for a better understanding of the proposal by the communities, on the one hand, and the listening to their local demands, on the other, in a process of mutual learning.

Future developments. The challenge here is to establish strategies for project continuity together with the communities. One of the planned actions is to continue and to expand partnerships with local schools. This proposal is in line with the construction of learning communities for disaster risk reduction, a strategy that also involves the ongoing cooperation of the National Centre for Monitoring and Early Warnings of Natural Disasters (Cemaden) through its Cemaden-Education project.

Another alternative is to generate the participatory approach coupled with new strategies to communicate data and results to communities, identified as relevant during the research with the communities, while presenting benefits for reducing soil loss caused by extreme rains and consequent floods. The main alternative proposed was to strengthen agroforestry systems as a land use strategy for subsistence purposes. This initiative has already been tried out with the support of the Hydrographic Watershed Committee of the North Coast of São Paulo, through the Technical Group on Agroecology and Agroforestry Systems ${ }^{9}$ and the Agroecology group of Observatory of Territory Sustainable and Health (OTSS in Portuguese) ${ }^{10}$, and with the support of researchers engaged in the preparation of proposals to raise funds for new projects. Also, to create a local economy of organic products through training and articulation with local producers to carry out joint purchases of material for these crops.

Expand the ways of recording information. The creation of a strategy with community groups was suggested so that photographic records of changes in the surroundings of their homes and neighborhoods can be inserted into platforms such as QGIS, or Google Maps or Google Earth itself. Other proposals were for recording these observations in workbooks; using artisanal rain gauges to measure the amount of rain and the associated flood risks, in a given location; building a timeline with the community on the occurrence of extreme weather events and the problems generated in those territories; and preparing a participatory $3 \mathrm{D}$ model for visualization of the territory.

Open data, for whom? Finally, the exercise fostered a debate about the possible uses of data produced by community mapping which may eventually be contrary to the interests of those communities. More specifically, it was pointed out that information on territorial overlaps with protected areas was used to incriminate people from those communities. Citizen science initiatives, in line with the open science principles, must give transparency to the research procedures and to the use of its results.

\section{Conclusions}

The right to research proposed by Appadurai, when applied as a Social Science conceptual approach to reframe the theoretical and empirical scopes of citizen science, reinforces two central aspects of its democratic perspective. One of them is the idea that research is a right, that is, a requirement for the full exercise of citizenship, playing a role in disputes and conflicts over the uses of territory. The other aspect refers to the recognition of the range of actors who are able to carry out research and obtain significant results both for the advancement of knowledge and for 
confronting issues relevant to the well-being of societies and the equilibrium of the planet.

In this study, the right to research was exerted through practical experimentation by the locals as research agents, combining citizen science, action research and social cartography methods. Bringing affected communities together around climate change adaptation topics and strategies can help to engage and "empower" them in risk management strategies. Stronger recognition of their perception of risk may increase the possibilities and conditions for their engagement in these actions, strengthening their resilience to the risks and disasters of climate change, and increasing their influence in the design of strategies and public policies in this field. Involving and incorporating knowledge of local communities about that territory, by mobilising participatory methods and community-based data-feeding tools, has the potential to broaden and democratise the perspective of environmental research as well as to increase learning and the effectiveness of actions and policies in dealing with climate change.

On the other hand, citizen science and other participatory approaches are not enough to subvert information and knowledge asymmetries and power relations. Capacity building, digital inclusion and open infrastructure are needed to enhance participatory citizen science and mapping tools. Crucial to these are the protocols and forms of governance that make room for the recognition of the points of view of different social and cognitive actors. Above all, it is necessary to establish more democratic governance systems for decision-making processes on territory management that affect citizen participation in climate change issues (Albagli et al. 2019). Hence, there are close relationship between citizen science, open infrastructure, and data justice.

For the new editions of the CoAdapta project, which have developed citizen science toolkits for observations on climate change, it is expected that research protocols be formulated more openly, both in the decision-making process about the steps of the research, as in the social appropriation of citizen data.

\section{Data availability}

The dataset generated or analysed during this study is not publicly due to privacy restrictions because involved human participants. Partially data from this project is available on the website https:// www.coadaptalitoral.net/mapping-platform.html and from the corresponding author on reasonable request.

Received: 2 September 2020; Accepted: 10 January 2022;

Published online: 01 February 2022

\footnotetext{
Notes

1 The river basin is defined by Brazil's National Civil Protection and Defense Policy (2012) as the territorial unit for analysis and disaster prevention actions related to bodies of water (Cemaden Educação).

2 See more at https://www.coadaptalitoral.net/.

3 https://www.google.com/maps/d/u/0/viewer?mid=15lHnzhEvahbrmOyt0jyD8tzjsA\&ll $=4.312356666109498 \% 2 \mathrm{C}-44.71811151281769 \& \mathrm{z}=12$.

4 Available at: http://educacao.cemaden.gov.br/site/news/ODYwMDAwMDAwMTA5.

5 See more at https://www.coadaptalitoral.net/mapping-platform.html.

6 http://educacao.cemaden.gov.br/site/project/ | http://educacao.cemaden.gov.br/site/ map/.

7 https://wiki.ubatuba.cc/doku.php?id=coadapta_litoral:coadapta.

8 https://www.coadaptalitoral.net/.

9 https://cbhln.com.br/ct-agrosafs.

10 https://www.otss.org.br/agroecologia.
}

\section{References}

Acselrad H (org.) (2013) Cartografia social, terra e território. IPPUR/UFRJ, Rio de Janeiro, p 318

Adger WN, Brown I, Surminski S (2018) Advances in risk assessment for climate change adaptation policy. Phil. Trans. R. Soc. A. 376:20180106. https:// doi.org/10.1098/rsta.2018.0106

Albagli S, Maciel ML, Abdo AH (2015) Open science, open issues. Ibict, Brasilia. http://livroaberto.ibict.br/handle/1/1061

Albagli S, Parra H, Fonseca FS, Maciel ML (2019) Open science and social change: a case study in Brazil. Contextualizing Openness: Situating Open Science. University of Ottawa Press, Ottawa, p 291-310. https://repositorio.unifesp.br/ handle/11600/53348

Albagli S, Py H, Iwama AY (2020) Data Geovisualization and Open and Citizen Science - the LindaGeo Platform Prototype. http://www.digitalhumanities. org/dhq/vol/14/2/000452/000452.html 14 .

Anazawa TM (2018) A escassez hídrica na Região Metropolitana de Campinas entre 2013-2015: a perspectiva de um desastre socialmente construído. Cad. Metrop. 20:347-369. https://doi.org/10.1590/2236-9996.2018-4203

Anderson SE, Bart RR, Kennedy MC, MacDonald AJ, Moritz MA, Plantinga AJ, Tague CL, Wibbenmeyer M (2018) The dangers of disaster-driven responses to climate change. Nature Clim Change 8:651-653. https://doi.org/10.1038/ s41558-018-0208-8

Appadurai A (2006) The right to research. Globalisation, Societies and Education 4:167-177. https://doi.org/10.1080/14767720600750696

Baumgartner L and Zarestky J. (2017) Community engagement in climate change: models of culturally appropriate citizen science: theorizing from the literature. Adult Education Research Conference. https://newprairiepress.org/aerc/ 2017/papers/30

Birkmann J, Tetzlaff G, Zentel K-O (2009) Addressing the challenge: recommendations and quality criteria for linking disaster risk reduction and adaptation to climate change. German Committee for Disaster Reduction, Bonn, https:// www.preventionweb.net/publication/addressing-challengerecommendations-and-quality-criteria-linking-disaster-risk

Bonney R, Cooper CB, Dickinson J, Kelling S, Phillips T, Rosenberg KV, Shirk J (2009) Citizen science: a developing tool for expanding science knowledge and scientific literacy. BioScience 59:977-984. https://doi.org/10.1525/ bio.2009.59.11.9

Bonney R, Shirk JL, Phillips TB, Wiggins A, Ballard HL, Miller-Rushing AJ, Parrish JK (2014) Next steps for citizen science. Science 343:1436-1437. https:// doi.org/10.1126/science.1251554

Bradley GL, Babutsidze Z, Chai A, Reser JP (2020) The role of climate change risk perception, response efficacy, and psychological adaptation in proenvironmental behavior: a two nation study. Journal of Environmental Psychology 68, https://doi.org/10.1016/j.jenvp.2020.101410

Cadag JR, Driedger C, Garcia C, Duncan M, Gaillard JC, Lindsay J et al. (2018) Fostering participation of local actors in volcanic disaster risk reduction. In: Fearnley CJ, Bird DK, Haynes K, McGuire WJ, Jolly G (eds.) Observing the Volcano World: Volcano Crisis Communication. Springer International Publishing, Cham, 10.1007/11157_2016_39

Chari R, Blumenthal M, Matthews L (2019) Community Citizen Science: From Promise to Action. RAND Corporation. https://doi.org/10.7249/RR2763

Cinner JE, Adger WN, Allison EH, Barnes ML, Brown K, Cohen PJ, Gelcich S, Hicks CC, Hughes TP, Lau J, Marshall NA, Morrison TH (2018) Building adaptive capacity to climate change in tropical coastal communities. Nature Clim Change 8:117-123. https://doi.org/10.1038/s41558-017-0065-x

Collins HM, Evans R (2002) The third wave of science studies: studies of expertise and experience. Social Studies of Science 32:235-296. https://doi.org/10.1177/ 0306312702032002003

Comandulli C, Vitos M, Conquest G, Altenbuchner J, Stevens M, Lewis J, Haklay ME (2016) Ciência Cidadã Extrema: Uma Nova Abordagem. Biodiversidade Brasileira, v. 6, n.1, 34-47. https://discovery.ucl.ac.uk/id/eprint/1572313/

Crampton JW (2001) Maps as social constructions: power, communication and visualization. Progress in Human Geography 25(2):235-252. https://doi.org/ $10.1191 / 030913201678580494$

Cutter SL, Emrich CT, Webb JJ, Morath D (2009) Social Vulnerability to Climate Variability Hazards: A Review of the Literature. University of South Carolina, Columbia

David-Chavez DM, Gavin MC(2018) A global assessment of Indigenous community engagement in climate research Environ Res Lett 13:123005. https:// doi.org/10.1088/17489326/aaf300

Dickinson JL, Shirk J, Bonter D, Bonney R, Crain RL, Martin J, Phillips T, Purcell K (2012) The current state of citizen science as a tool for ecological research and public engagement. Frontiers in Ecology and the Environment 10:291-297. https://doi.org/10.1890/110236

Ensor JE, Park SE, Attwood SJ, Kaminski AM \& Johnson JE (2016) Can community-based adaptation increase resilience? Climate and Development, https://doi.org/10.1080/17565529.2016.1223595 
Fell R, Corominas J, Bonnard C, Cascini L, Leroi E, Savage WZ (2008) Guidelines for landslide susceptibility, hazard and risk zoning for land use planning. Engineering Geology 102:85-98. https://doi.org/10.1016/j.enggeo.2008.03.022

Funtowicz S, and Ravetz J (1997) Environmental problems, post-normal science, and extended peer communities. Études et Recherches sur les Systèmes Agraires et le Développement, INRA Editions, 1997, 169-175. https:// hal.archives-ouvertes.fr/hal-01231607

Di Giulio GM, Serrao-Neumann S, Viglio JE, Ferreira LC, Choy DL (2014) Methodological proposals for research on risk and adaptation: experiences in Brazil and Australia. Ambient Soc 17 (4). https://doi.org/10.1590/180944ASOC895V1742014

Goodman LA (1961) Snowball sampling. Annals of Mathematical Statistics 32(1):148-170. https://doi.org/10.1214/aoms/1177705148

Haklay M (2013) Citizen Science and Volunteered Geographic Information: Overview and Typology of Participation. In: Sui D, Elwood S, Goodchild M (Eds.) Crowdsourcing Geographic Knowledge. Springer, Netherlands, Dordrecht, p 105-122.

Hicks A, Barclay J, Chilvers J, Armijos MT, Oven K, Simmons P, Haklay M (2019) Global mapping of citizen science projects for disaster risk reduction. Front. Earth Sci. 7:226. https://doi.org/10.3389/feart.2019.00226

IPCC (2014) Climate Change 2014: Synthesis Report. Contribution of Working Groups I, II and III to the Fifth Assessment Report of the Intergovernmental Panel on Climate Change. https://www.ipcc.ch/report/ar5/syr/

Irwin A (1995) Citizen Science: A Study of People, Expertise and Sustainable Development. Routledge, London

Iwama AY, Araos F, Anbleyth-Evans J, Marchezini V, Ruiz-Luna A, Ther-Ríos F, Bacigalupe G, Perkins PE (2021) Multiple knowledge systems and participatory actions in slow-onset effects of climate change: insights and perspectives in Latin America and the Caribbean. Current Opinion in Environmental Sustainability 50(2021):31-42. https://doi.org/10.1016/ j.cosust.2021.01.010

Iwama AY (2018) Adaptação às mudanças climáticas e cartografia social: uma abordagem com foco na ciência cidadã. Projeto de pesquisa de posdoutoramento pelo Programa FAPERJ. IBICT-UFRJ (Pos-Graducao em Ciencia da Informacao). 36p. https://wiki.ubatuba.cc/doku.php? id $=$ coadapta_litoral:coadapta

Iwama AY, Batistella M, Ferreira Lucia C, Alves DS, Ferreira Leila C (2016) Risk, vulnerability and adaptation to climate change: an interdisciplinary approach. Ambient. Soc. 19:93-116. https://doi.org/10.1590/1809-4422ASOC137409 V1922016

Iwama AY, Batistella M, Ferreira LC (2014) Geotechnical risks and social vulnerability in coastal areas: inequalities and climate change. Ambient. Soc. 17. https://doi.org/10.1590/1809-4422ASOC1149V1742014

Iwama AY, Teixeira LR, Batistella M, Ferreira LC (2013) Inter-dependent, Interconnected Technological and Environmental Risks in the Context of Climate Change. UNISDR.

Keefer P, Neumayer E, Plümper T (2011) Earthquake propensity and the politics of mortality prevention. World Development 39:1530-1541. https://doi.org/ 10.1016/j.worlddev.2011.02.010

Kenens J, Van Oudheusden M, Yoshizawa G et al. (2020) Science by, with and for Citizens: Rethinking 'Citizen Science' After the 2011 Fukushima Disaster. Palgrave Communications 6:58. https://doi.org/10.1057/s41599-020-0434-3

Kondo Y, Miyata A, Ikeuchi U, Nakahara S, Nakashima K, Ōnishi H, Osawa T, Ota K, Sato K, Ushijima K, Baptista BV, Kumazawa T, Hayashi K, Murayama Y, Okuda N, Nakanishi H (2019) Interlinking open science and community-based participatory research for socio-environmental issues. Current Opinion in Environmental Sustainability 39:54-61. https://doi.org/10.1016/j.cosust.2019.07.001

Lam DPM, Hinz E, Lang DJ, Tengö M, von Wehrden H, Martín-López B(2020) Indigenous and local knowledge in sustainability transformations research: a literature review E\&S 25:25. https://doi.org/10.5751/ES-11305-250103

Leiserowitz A (2006) Climate change risk perception and policy preferences: the role of affect, imagery, and values. Climatic Change 77:45-72. https://doi.org/ 10.1007/s10584-006-9059-9

McCall MK, Peters-Guarin G (2012) Participatory action research and disaster risk. In: Wisner, Gaillard, and Kelman (eds). Handbook of Hazards and Disaster Risk Reduction. Routledge. pp. 727-741. ISBN: 9780415523257

McCall MK, Martinez J, Verplanke J (2015) Shifting boundaries of Volunteered Geographic Information systems and modalities: learning from PGIS. ACME An International E-Journal for Critical Geographies 14(3):791-826. https:// acme-journal.org/index.php/acme/article/view/1234/1028

McCall MK (2014) Mapping territories, land resources and rights: communities deploying participatory mapping/PGIS in Latin America. Revista do Departamento de Geografia, Universidade de São Paulo, Volume Especial Cartogeo, 94-122. https://doi.org/10.7154/RDG.2014.0114.0004

Marchezini V, Horita FEA, Matsuo PM, Trajber R, Trejo-Rangel MA, Olivato D (2018) A review of studies on participatory early warning systems (P-EWS): pathways to support citizen science initiatives. Front. Earth Sci. 6:184. https:// doi.org/10.3389/feart.2018.00184
Marchezini V, Iwama AY, Andrade MRM, Trajber R, Rocha I, Olivato D (2017) Geotecnologias para Prevenção de Riscos de Desastres: Usos e Potencialidades dos Mapeamentos Participativos. Revista Brasileira de Cartografia, 107-128.

Marchezini V, Iwama AY, Pereira DC, da Conceição RS, Trajber R, Olivato D (2019) Designing a cultural heritage articulated warning system (CHAWS) strategy to improve disaster risk preparedness in Brazil. Disaster Prevention and Management 29:65-85. https://doi.org/10.1108/DPM-07-2018-0227

Mercer J, Gaillard JC, Crowley K, Shannon R, Alexander B, Day S et al. (2012) Culture and disaster risk reduction: lessons and opportunities. Environ. Hazards 11:74-95. https://doi.org/10.1080/17477891.2011.609876

Merkens J-L, Reimann L, Hinkel J, Vafeidis AT (2016) Gridded population projections for the coastal zone under the shared socioeconomic pathways. Global and Planetary Change 145:57-66. https://doi.org/10.1016/ j.gloplacha.2016.08.009

Morgan J, Dagnet Y, Tirpak D (2014) Elements and ideas for the 2015 Paris Agreement, Working Paper ACT 2015. World Resources Institute. https:// www.wri.org/research/elements-and-ideas-2015-paris-agreement

Mosites E, Lujan E, Brook M, Brubaker M, Roehl D, Tcheripanoff M, Hennessy T (2018) Environmental observation, social media, and one health action: a description of the local environmental observer (LEO) network. One Health 6:29-33. https://doi.org/10.1016/j.onehlt.2018.10.002

Nobre AD, Cuartas LA, Momo MR, Severo DL, Pinheiro A, Nobre CA(2016) HAND contour: a new proxy predictor of inundation extent Hydrol. Process 30:320-333. https://doi.org/10.1002/hyp.10581

Pacheco FS, Miranda M, Pezzi LP, Assireu A, Marinho MM, Malafaia M, Reis A, Sales M, Correia G, Domingos P, Iwama AY, Rudorff C, Oliva P, Ometto JP (2017) Water quality longitudinal profile of the Paraíba do Sul River, Brazil during an extreme drought event: water quality during an extreme drought. Limnol. Oceanogr. 62:S131-S146. https://doi.org/10.1002/lno.10586

Paul JD, Buytaert W, Allen S, Ballesteros-Cánovas JA, Bhusal J, Cieslik K, Clark J, Dugar S, Hannah DM, Stoffel M, Dewulf A, Dhital MR, Liu W, Nayaval JL, Neupane B, Schiller A, Smith PJ, Supper R (2018) Citizen science for hydrological risk reduction and resilience building. WIREs Water 5:e1262. https://doi.org/10.1002/wat2.1262

Paul JD, Hannah DM, Liu W (Eds.) (2020) Citizen science: reducing risk and building resilience to natural hazards, frontiers research topics. Front. Media SA. https://doi.org/10.3389/978-2-88963-401-9

Rennó CD, Nobre AD, Cuartas LA, Soares JV, Hodnett MG, Tomasella J, Waterloo MJ (2008) HAND, a new terrain descriptor using SRTM-DEM: mapping terra-firme rainforest environments in Amazonia. Remote Sensing of Environment 112:3469-3481. https://doi.org/10.1016/j.rse.2008.03.018

Reyes-García V, García-del-Amo D, Benyei P, Fernández-Llamazares Á, Gravani K, Junqueira AB, Labeyrie V, Li X, Matias DM, McAlvay A, Mortyn PG, Porcuna-Ferrer A, Schlingmann A, Soleymani-Fard R (2019) A collaborative approach to bring insights from local observations of climate change impacts into global climate change research. Current Opinion in Environmental Sustainability 39:1-8. https://doi.org/10.1016/j.cosust.2019.04.007

Sauermann H, Vohland K, Antoniou Y, Balázs B, Göbel C, Karatzas K, Mooney P, Perelló J, Ponti M, Samson R, Winter S (2020) Citizen science and sustainability transitions. Research Policy 49(5):103978. https://doi.org/10.1016/ j.respol.2020.103978

Savo V, Lepofsky D, Benner JP, Kohfeld KE, Bailey J, Lertzman K (2016) Observations of climate change among subsistence-oriented communities around the world. Nature Clim. Change 6:462-473. https:/doi.org/10.1038/ nclimate2958

Serrao-Neumann S, Di Giulio G, Low Choy D (2020) When salient science is not enough to advance climate change adaptation: lessons from Brazil and Australia. Environmental Science \& Policy 109:73-82. https://doi.org/ 10.1016/j.envsci.2020.04.004

Shirk JL, Ballard HL, Wilderman CC, Phillips T, Wiggins A, Jordan R, McCallie E, Minarchek M, Lewenstein BV, Krasny ME, Bonney R (2012) Public participation in scientific research: a framework for deliberate design. Ecology and Society 17:29. https://doi.org/10.5751/ES-04705-170229

Simões E, Navarro FCS, Bussolotti J, Alves Jr JI (2016) Planejamento Ambiental da Bacia Hidrográfica do Ubatumirim: Instrumento de Justiça Socioambiental, 1st ed. Páginas e Letras, Sao Paulo, ISBN 978-85-8191-058-1

Slovic P, Finucane ML, Peters E, MacGregor DG (2010) Risk as analysis and risk as feelings: some thoughts about affect, reason, risk and rationality. In: Slovic $\mathrm{P}$ (ed) The Feeling Risk: New Perspectives on Risk Perception. Earthscan, London, $\mathrm{p} 21-36$.

Stevens M, Vitos M, Altenbuchner J, Conquest G, Lewis J, Haklay M (2014) Taking participatory Citizen Science to Extremes. IEE Pervasive Computing 13(2):20-29. https://doi.org/10.1109/MPRV.2014.37

Teixeira LR, Iwama AY (2017) Caracterização dos Grandes Projetos de Infraestrutura do Litoral Norte Paulista, in: Rumos Da Sustentabilidade Costeira: Uma Visão Do Litoral Norte Paulista. Instituto Oceanográfico da Universidade de São Paulo, São Paulo, pp. 98-153. 
Tengö M, Hill R, Malmer P, Raymond CM, Spierenburg M, Danielsen F, Elmqvist T, Folke C (2017) Weaving knowledge systems in IPBES, CBD and beyondlessons learned for sustainability. Curr Opin Environ Sustain, 26-27:17-25. https://doi.org/10.1016/j.cosust.2016.12.005

Trajber R, Walker C, Marchezini V, Kraftl P, Olivato D, Hadfield-Hill S, Zara C, Fernandes Monteiro S (2019) Promoting climate change transformation with young people in Brazil: participatory action research through a looping approach. Action Research 17:87-107

Udvarhelyi ÉT (2011) Reflections on a politics of research for the right to the city. International Review of Qualitative Research 3:383-401. https:/doi.org/ 10.1525/irqr.2011.3.4.383

UN (2016) Indigenous and Local Knowledge(s) and Science(s) for Sustainable Development. Scientific Advisory Board of the UN Secretary-General 12. https://unesdoc.unesco.org/ark:/48223/pf0000246104

\section{Acknowledgements}

We thank Dr. Maria Cristina Matos Nogueira for proofreading the text in English. Special thanks for the collaboration of local and traditional communities, that are part of the Forum of Traditional Communities of Angra dos Reis, Paraty and Ubatuba together with Observatory of Sustainable and Healthy Territories (OTSS in Portuguese) in Bocaina. The research project was funded by the Carlos Chagas Filho Foundation for Supporting Research in the State of Rio de Janeiro--FAPERJ [E-26/202.413/2017], the Brazilian National Council for Scientific and Technological Development--CNPq [437095/2018-5], ANID/FONDECYT [3180705/2018], IDRC/SSHRC through Queen Elizabeth Scholars project on "Ecological Economics, Commons Governance, and Climate Justice" [2017-0082].

\section{Competing interests}

The authors declare no competing interests.

\section{Ethical approval}

The authors confirmed that the research was analysed and certified by the Bioethics and Biosafety Committee of the Universidad de los Lagos, Chile. We testify that the referred methods and procedures follow the international standards for research ethics, according with Declaration of Helsinki.

\section{Informed consent}

The authors confirmed that the informed consent was obtained from all participants in the study by means of a written, signed and dated informed consent form.

\section{Additional information}

Supplementary information The online version contains supplementary material available at https://doi.org/10.1057/s41599-022-01040-8.

Correspondence and requests for materials should be addressed to Sarita Albagli or Allan Yu Iwama.

Reprints and permission information is available at http://www.nature.com/reprints

Publisher's note Springer Nature remains neutral with regard to jurisdictional claims in published maps and institutional affiliations.

\begin{abstract}
cc (i) Open Access This article is licensed under a Creative Commons Attribution 4.0 International License, which permits use, sharing, adaptation, distribution and reproduction in any medium or format, as long as you give appropriate credit to the original author(s) and the source, provide a link to the Creative Commons license, and indicate if changes were made. The images or other third party material in this article are included in the article's Creative Commons license, unless indicated otherwise in a credit line to the material. If material is not included in the article's Creative Commons license and your intended use is not permitted by statutory regulation or exceeds the permitted use, you will need to obtain permission directly from the copyright holder. To view a copy of this license, visit http://creativecommons.org/ licenses/by/4.0/
\end{abstract}

(C) The Author(s) 2022 